
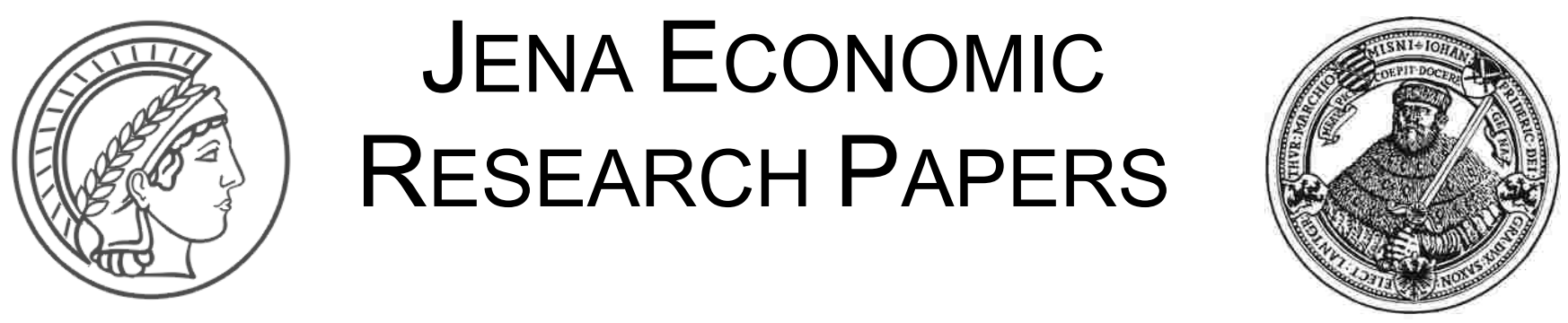

\# $001-2007$

\title{
The Geography and the Effect of Creative People in Germany
}

\author{
by \\ Michael Fritsch \\ www.jenecon.de \\ ISSN
}

The Jena ECONOmic Research PAPERS is a joint publication of the Friedrich-SchillerUniversity and the Max Planck Institute of Economics, Jena, Germany. For editorial correspondence please contact m.pasche@wiwi.uni-jena.de.

Impressum:

Friedrich-Schiller-University Jena

Carl-Zeiß-Str. 3

D-07743 Jena

www.uni-jena.de

(C) by the author.
Max-Planck-Institute of Economics

Kahlaische Str. 10

D-07745 Jena

www.econ.mpg.de 


\title{
The Geography and the Effect of Creative People in Germany
}

April 2007

\author{
Michael Fritsch \\ Friedrich Schiller University Jena, Faculty of Economics and Business \\ Administration, Max Planck Institute of Economics, Jena, and German \\ Institute for Economic Research (DIW) Berlin, Germany. \\ m.fritsch@uni-jena.de
}

\begin{abstract}
This paper investigates the geography and the effect of people in creative occupation in Germany. The population share of the Creative Class as well as of bohemians and artists is relatively high in larger cities, but smaller places and rural regions may also have a considerable proportion of people with a creative job. While ethnical and cultural diversity and a high level of public supply in health care and education can explain the distribution of creative people, employment opportunities seem to play only a minor role. There is a positive statistical relationship between the share of people in creative occupations, the level of new business formation and the innovativeness of regions. A high share of creative occupations seems to be conducive to regional growth; however, the exact nature of this relationship is still unclear.
\end{abstract}

JEL-Classification: O31, O18, R11

Keywords: Creativity, innovation, entrepreneurship, regional development 


\section{Creativity and growth}

Creativity as a source of growth has gained increasing attention in recent years. Creativity is the ability to create new knowledge or to transform existing knowledge. In his book „The Rise of the Creative Class" (2004), ${ }^{1}$ Richard Florida has shown that the part of the population in the USA which is active in creative occupations is distributed rather unequal in space. According to Florida's analysis, people in creative occupations are concentrated in some few large cityregions, which he regards as centers of technical and social innovation. Accordingly, the creative cities can be regarded as hothouses for future growth and development. Florida goes one step further in arguing that the creative people have pronounced locational preferences and that they represent a main source for attracting innovative activity from outside the region. His recommendation for regional policy makers is, therefore, to create a suitable environment for creative people in order to account for the key importance of this part of the regional population.

This paper analyzes the geography and the effect of people with creative occupations in Germany. Where do these people live and work? What characterizes regions with a high share of creative population? Do these regions exhibit high levels of innovation, entrepreneurship and growth? Following an introduction of some basic hypotheses (section 2), the indicators for a creative population are introduced (section 3). Section 4 gives an overview of the regional distribution of the creative people. Results of multivariate analyses of the share of the population in creative occupations are presented in section 5 . Section 6 investigates into the relationship between the share

\footnotetext{
${ }^{1}$ The first edition of the book appeared in 2002. I refer to the revised paperback edition from 2004.
} 
of creative people, innovation, entrepreneurship and growth. Section 7 concludes.

\section{Basic hypotheses}

Florida (2003, 40; 2004) identifies "three interrelated types of creativity: (1) technological creativity or innovation, (2) economic creativity or entrepreneurship, and (3) artistic or cultural creativity." He argues that these three types of human creativity influence and reinforce each other and that they are important drivers of regional development. According to Florida, a main factor in explaining creativity driven growth is the locational choice of creative people. He suggests that creative people do not solely base their decision to live in a certain location because of job opportunities available there. According to him, factors such as the variety of the cultural supply, tolerance and openness towards new ideas, towards people of different ethnical background, of different sexual orientation or different styles of living are just as important as the regional labor market. Florida $(2004,259)$ assumes that creative people prefer a diversity of small-scale cultural activities with a vibrant night life and an innovative music scene over traditional cultural events such as museums, operas, ballets or professional sports teams.

According to Florida (2004) these factors are important for two reasons. First, it is easier for people integrate in such an environment without having to abandon their own identity. Second, tolerance and openness may lead to variety. This gives creative people the opportunity to gain new experiences that can be a stimulus and inspiration for creative processes (Florida, 2004, 218, 249f.; Andersen and Lorenzen, 2005, 12). Florida (2004) applies a number of indicators for openness, tolerance and cultural variety such as the share of foreign born population (Melting Pot Index), the share of people in artistic occupations (Bohemian Index) or the share of homosexual people (Gay Index). For the USA, these indicators show a pronounced concentration 
of creative people in certain cities such as Washington D.C., Boston, Austin and San Francisco. A further important element of Florida's approach is the hypothesis that the creative people show no pronounced tendency to locate in regions where they can expect to to have good employment opportunities ('people follow jobs') but rather the firms locate in the regions where they are able to find the creative people they need ('jobs follow people'). Therefore, the concentration of creative people in a few locations can be regarded as a reason for the clustering of economic activity. This is particularly true for activities with a high demand for high qualified labor such as Research and Development, design and marketing and high-tech industries (Arora et al., 2000, 12). Florida's argument is congruent to Jane Jacobs' (1970, 1985) ideas about the important role of cities as well as the basic hypotheses of the new economic growth theory (Lucas, 1988; Romer, 1986; 1993).

A main reason why variety and creativity may provide a good breeding ground for innovation and entrepreneurship is that they stimulate the encounter of people with different backgrounds and the combination of their knowledge (Desrochers, 2001). This newly combined knowledge may then constitute an important source of innovation and the formation of new firms which are important drivers of economic development (Schumpeter, 1911; Feldman, 2000; Fritsch and Mueller, 2004). ${ }^{2}$ Florida and Gates (2001) and Lee, Florida and Gates (2002) show that there is a positive empirical relationship between ethnical diversity and innovation in US metropolitan areas. Lee, Florida

\footnotetext{
${ }^{2}$ A main reason for a person to set up a new firm is that knowledge and ideas may hardly be tradable on the market. Therefore, setting up an own firm may be the only way for someone to realize her or his ideas (Audretsch, 1995, 47-55; Wennekers und Thurik, 1999, 49f.; Klepper und Sleeper, 2005).
} 
and Acs (2004) find a significantly positive relationship between the share of creative employment in a region and the level of start-ups.

A main criticism about Florida's approach is that he confuses creativity and human capital (e.g., Markusen, 2003, 4; Glaeser, 2004). This criticism is mainly directed towards the definition of creative people for the empirical analysis on the basis of occupations. Many of the occupations that Florida regards as creative require a relatively high level of qualification. Thus, his critics state that he measures the impact of qualification and human capital on economic development. This kind of critique is correct to the extent that there tends to be a highly positive correlation between the share of people in creative occupations and the share of people with a higher level of education. However for the contribution to economic development, it may be important how qualification is applied. A taxi driver with a Ph.D. may be highly qualified, but is he more creative than other people? Even if he would be a rather creative taxi driver, can he in his position have a significant influence on the creation and the application of new ideas?

A further point of criticism is directed towards the impact of people in artistic occupations, the bohemians, on economic development (Malizia and Feser in Lang and Danielsen, 2005, 213; Markusen, 2006, 6). These critics doubt that there is a causal relationship between a high share of bohemians in a region and economic development.

\section{Who are the creative people?}

Florida's Creative Class $(2004,8)$ consists of people that "engage in complex problem solving that involves a great deal of independent judgment and requires high levels of education of human capital. ... Those ... in the Creative Class are primarily paid to create and have considerable more autonomy and flexibility than the other ... classes to do so." According to Florida, the core of the Creative Class includes 
"people in science and engineering, architecture and design, education, arts, music and entertainment, whose economic function is to create new ideas, new technology and/or new creative content" (ibid.). Surrounding this creative core is "a broader group of creative professionals in business and finance, law, health care and related fields" (ibid.). An important sub-group of the creative core is the bohemians, which includes the artistically creative people such as "authors, designers, musicians, composers, actors, directors, painters, sculptors, artists, printmakers, photographers, dancers, artists, and performers" (Florida, 2004, 333).

For the empirical analysis, the different categories of creative people are identified by their occupation. The main data source used for this is the German Social Insurance Statistics (see Fritsch and Brixy, 2004, for a brief description). All persons contained in the statistics can be assigned to the place of their employment. This information was classified according to the International Standard Classification of Occupations (ISCO) in the version of 1988 (see for the ISCO classification Elias, 1997). Table 1 shows the definitions of the different types of creative occupations according to the ISCO classification. ${ }^{3}$

A shortcoming of the German Social Insurance Statistics is that entrepreneurs, freelancers and civil servants are not included. This is particularly relevant for the bohemians because many of these occupations are characterized by a relatively high share of freelancers. It is estimated that about half of the active artists in Germany are

\footnotetext{
${ }^{3}$ These are the definitions applied in the joint project ,Technology, Talent and Tolerance in European Cities: A Comparative Analysis" in which the author is involved. The main goal of this project is an international comparison of the role of the Creative Class for regional development. Other team leaders involved in this project are Björn Asheim (Lund), Ron Boschma (Utrecht), Phil Cooke (Cardiff), Meric S. Gertler (Toronto), Arne Isaksen (Oslo), Mark Lorenzen (Copenhagen), Markku Sotarauta (Tampere) as well as Tina Haisch and Christof Kloepper (Basle). For an international comparison see Boschma and Fritsch (2007).
} 
Table 1: The creative occupations

\begin{tabular}{|c|c|}
\hline $\begin{array}{l}\text { Groups of } \\
\text { creative } \\
\text { people }\end{array}$ & Occupations (ISCO-Code) \\
\hline Creative core & $\begin{array}{l}\text { Physicists, chemists and related professionals (211); } \\
\text { Mathematicians, statisticians and related professionals (212); } \\
\text { Computing professionals (213); } \\
\text { Architects, engineers and related professionals (214); } \\
\text { Life science professionals (221); } \\
\text { Health professionals (except nursing) (222); } \\
\text { College, university and higher education teaching professionals (231); } \\
\text { Secondary education teaching professionals (232); } \\
\text { Primary and pre-primary education teaching professionals (233); } \\
\text { Special education teaching professionals (234); } \\
\text { Other teaching professionals (235); } \\
\text { Archivists, librarians and related information professionals (243); } \\
\text { Social sciences and related professionals (244); } \\
\text { Public service administrative professionals (247). }\end{array}$ \\
\hline $\begin{array}{l}\text { Creative } \\
\text { professionals }\end{array}$ & $\begin{array}{l}\text { Legislators, senior officials and managers (1); } \\
\text { Nursing and midwifery professionals (223); } \\
\text { Business professionals (241); } \\
\text { Legal professionals (242); } \\
\text { Physical and engineering science associate professionals (31); } \\
\text { Life science and health associate professionals (32); } \\
\text { Finance and sales associate professionals (341); } \\
\text { Business services agents and trade brokers (342); } \\
\text { Administrative associate professionals (343); } \\
\text { Police inspectors and detectives (345); } \\
\text { Social work associate professionals (346). }\end{array}$ \\
\hline $\begin{array}{l}\text { Employed } \\
\text { bohemians }\end{array}$ & $\begin{array}{l}\text { Writers and creative or performing artists (245); } \\
\text { Photographers and image and sound recording equipment operators } \\
\text { (3131); } \\
\text { Artistic, entertainment and sports associate professionals (347); } \\
\text { Fashion and other models (521). }\end{array}$ \\
\hline $\begin{array}{l}\text { Freelance } \\
\text { artists }\end{array}$ & Writers, performing arts, fine arts, music. \\
\hline
\end{tabular}

working as freelancers and are not recorded in the Social Insurance Statistics (Haak, 2005, 577). Information about the freelance artists is drawn from the Künstlersozialkasse, a special insurance created for those artists who are not in regular employment and, therefore, not subject to obligatory social insurance payments. ${ }^{4}$ According to this data source, the freelance artists are assigned to their place of residence.

${ }^{4} \mathrm{I}$ am indebted to Mr. Harro Bruns of the Künstlersozialkasse for providing these data. 
Information on a regional basis about entrepreneurs or civil servants that indicate the creativity of their activity is not available. Therefore, this category of people is not contained in the empirical analysis.

\section{Where do the creative people live and work?}

\subsection{Overview}

In the year 2004, the share of employees in creative occupations registered by the Social Insurance Statistics with the total population in Germany was 12.1 percent (table 2). The creative professionals made the largest part of the three sub-groups, accounting for 8.3 percent of population. The creative core occupations were the second largest group with a share of 3.2 percent. The share of employed bohemians made only 0.43 percent of the population. The share of the freelance artists was about 0.25 percent. The largest group among the freelance artists were in the fine arts $(0.09$ percent) followed by writers $(0.07$ percent), musicians ( 0.06 percent) and performing artists $(0.03$ percent).

In the 1987-2004 period, the share of creative occupations out of all employees in West Germany as recorded in the Social Insurance Statistics increased from 29.9 percent to 36.8 percent. The largest increase, from 5.7 to 9.9 percent, was in the share of the creative core occupations. ${ }^{5}$ Unfortunately, the information for the freelance artists does not allow meaningful longitudinal comparisons due to increasing coverage of the basic population over time (Haak, 2005, 593).

\footnotetext{
${ }^{5}$ In relation to the overall population, the share of employees in creative occupations increased from 10.6 percent in 1987 to 11.9 percent in 2004. The largest increase from 2.0 percent to 3.2 percent - was in the creative core category.
} 
More than half of the creative people of all categories live or work in the agglomerations ${ }^{6}$ while the share of creative people located in rural regions is less than 10 percent (table 2). Since the population is rather unevenly distributed among the different spatial categories, information on the share of creative people in different types of regions makes only limited sense. In order to judge to what extent a concentration of creative people in certain regions is, their share is related to the share of the population. This is done by calculating a location coefficient according to

$$
\text { Location coefficient }=\frac{\frac{{\text { Number of } \text { creatives }_{\text {region }}}_{\text {Population }} \text { region }}{\text { Number of creatives }_{\text {Germany }}}}{\text { Population }_{\text {Germany }}} .
$$

This location coefficient indicates to what extent the share of creative people in a region is above or below the national share. The more the value of the location coefficient exceeds unity, the more the share of creative people is above the national average. A value below unity indicates a share of people in creative occupations below the national average.

According to the location coefficients, the shares of the different types of creative people are above average mainly in cities (table 2). In rural areas and in the moderately congested regions, the value of the location coefficient is almost always below one; thus, indicating a relatively low share of creative people in this type of region. The maps with the population share of freelance artists and employed bohemians

\footnotetext{
${ }^{6}$ The definition of the spatial categories is from the Bundesamt für Bauwesen und Raumordnung (BBR) (2003).
} 
Table 2: Population share (\%) of people with creative occupations and location coefficients in different types of regions 2004 (share of population / location coefficient)

\begin{tabular}{|c|c|c|c|c|c|c|c|}
\hline & \multirow{2}{*}{ Germany } & \multicolumn{3}{|c|}{ Agglomerations } & \multicolumn{2}{|c|}{$\begin{array}{c}\text { Moderately congested } \\
\text { regions }\end{array}$} & \multirow{2}{*}{$\begin{array}{l}\text { Rural } \\
\text { areas }\end{array}$} \\
\hline & & Overall & $\begin{array}{l}\text { Core } \\
\text { cities }\end{array}$ & Rest & Overall & $\begin{array}{l}\text { Core } \\
\text { cities } \\
\end{array}$ & \\
\hline $\begin{array}{l}\text { Creative } \\
\text { class }\end{array}$ & $\begin{array}{c}12.1 / \\
1.00\end{array}$ & $\begin{array}{l}13.8 / \\
1.14\end{array}$ & $\begin{array}{l}18.9 / \\
1.56\end{array}$ & 9.9 / 0.81 & $\begin{array}{l}10.6 / \\
0.87\end{array}$ & $\begin{array}{l}19.1 / \\
1.57\end{array}$ & $9.4 / 0.78$ \\
\hline $\begin{array}{l}\text { Creative } \\
\text { core }\end{array}$ & $3.2 / 1.00$ & $3.8 / 1.18$ & $5.2 / 1.64$ & $2.6 / 0.81$ & $2.7 / 0.84$ & $5.4 / 1.68$ & $2.2 / 0.69$ \\
\hline $\begin{array}{l}\text { Creative } \\
\text { professionals }\end{array}$ & $8.3 / 1.00$ & $9.1 / 1.11$ & $\begin{array}{l}12.1 / \\
1.46\end{array}$ & $6.8 / 0.82$ & $7.4 / 0.90$ & $\begin{array}{l}12.6 / \\
1.53\end{array}$ & $6.9 / 0.84$ \\
\hline $\begin{array}{l}\text { Employed } \\
\text { bohemians }\end{array}$ & $\begin{array}{l}0.43 / \\
1.00\end{array}$ & $\begin{array}{l}0.57 / \\
1.33\end{array}$ & $\begin{array}{l}0.98 / \\
2.27\end{array}$ & $\begin{array}{l}0.26 / \\
0.60\end{array}$ & $\begin{array}{c}0.30 / \\
0.69\end{array}$ & $\begin{array}{c}0.83 / \\
1.93\end{array}$ & $\begin{array}{l}0.21 / \\
0.48\end{array}$ \\
\hline $\begin{array}{l}\text { Freelance } \\
\text { artists }\end{array}$ & $\begin{array}{l}0.25 / \\
1.00\end{array}$ & $\begin{array}{c}0.35 / \\
1.39\end{array}$ & $\begin{array}{l}0.58 / \\
2.31\end{array}$ & $\begin{array}{l}0.17 / \\
0.68\end{array}$ & $\begin{array}{l}0.15 / \\
0.60\end{array}$ & $\begin{array}{l}0.29 / \\
1.16\end{array}$ & $\begin{array}{l}0.13 / \\
0.50\end{array}$ \\
\hline - Writers & $\begin{array}{l}0.07 / \\
1.00\end{array}$ & $\begin{array}{l}0.10 / \\
1.50\end{array}$ & $\begin{array}{l}0.18 / \\
2.60\end{array}$ & $\begin{array}{l}0.04 / \\
0.57\end{array}$ & $\begin{array}{l}0.03 / \\
0.48\end{array}$ & $\begin{array}{c}0.07 / \\
0.99\end{array}$ & $\begin{array}{l}0.03 / \\
0.38\end{array}$ \\
\hline $\begin{array}{l}\text { - Performing } \\
\text { arts }\end{array}$ & $\begin{array}{c}0.03 / \\
1.00\end{array}$ & $\begin{array}{c}0.04 / \\
1.46\end{array}$ & $\begin{array}{l}0.08 / \\
2.60\end{array}$ & $\begin{array}{l}0.02 / \\
0.67\end{array}$ & $\begin{array}{l}0.02 / \\
0.53\end{array}$ & $\begin{array}{c}0.03 / \\
1.10\end{array}$ & $\begin{array}{l}0.01 / \\
0.41\end{array}$ \\
\hline - Music & $\begin{array}{c}0.06 / \\
1.00\end{array}$ & $\begin{array}{l}0.08 / \\
1.25\end{array}$ & $\begin{array}{l}0.12 / \\
1.87\end{array}$ & $\begin{array}{l}0.05 / \\
0.83\end{array}$ & $\begin{array}{l}0.05 / \\
0.76\end{array}$ & $\begin{array}{l}0.09 / \\
1.34\end{array}$ & $\begin{array}{l}0.04 / \\
0.61\end{array}$ \\
\hline - Fine arts & $\begin{array}{c}0.09 / \\
1.00\end{array}$ & $\begin{array}{c}0.12 / \\
1.38\end{array}$ & $\begin{array}{c}0.21 / \\
2.32\end{array}$ & $\begin{array}{l}0.06 / \\
0.67\end{array}$ & $\begin{array}{c}0.05 / \\
0.61\end{array}$ & $\begin{array}{c}0.11 / \\
1.18\end{array}$ & $\begin{array}{l}0.05 / \\
0.54\end{array}$ \\
\hline
\end{tabular}

make the differences between the two categories rather obvious (figure 1). The highest shares of freelance artists are found in Munich, Cologne, Berlin, Freiburg, Hamburg, Düsseldorf and Frankfurt (Main). There are also remarkably high shares of freelance artists in regions which are regarded as having a high quality of living such the area around Freiburg, the southern region below Munich which borders the Alps and at the German border near the Lake Constance (Bodensee). Compared to the freelance artists the employed bohemians are more evenly distributed in space. The share of employed bohemians is relatively high in the cities and tends to be low in remote rural areas. $A$ main reason why the locations of the freelance artists are more 


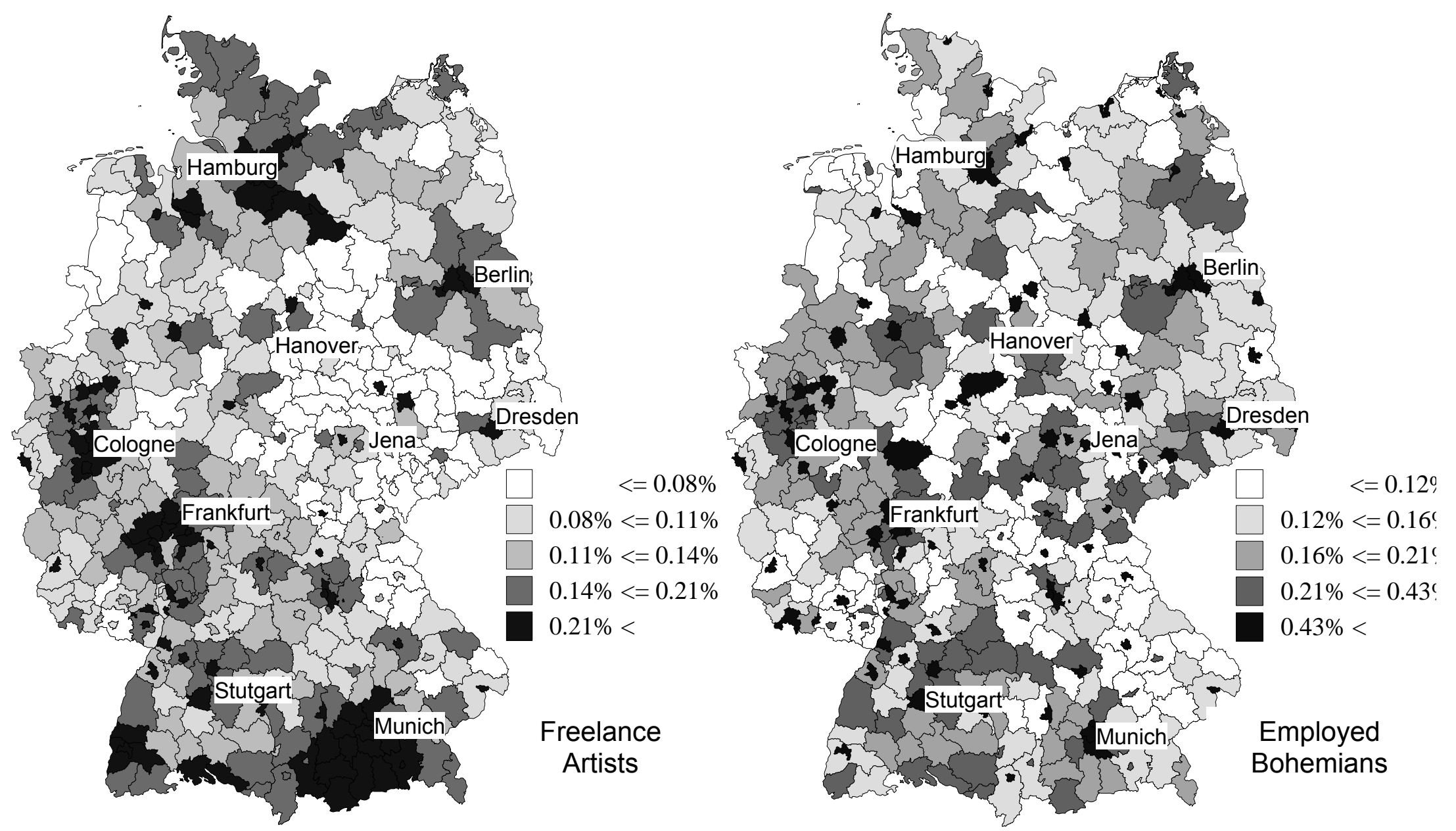

Figure 1: Population share of freelance artists and employed bohemians in German districts 2004 

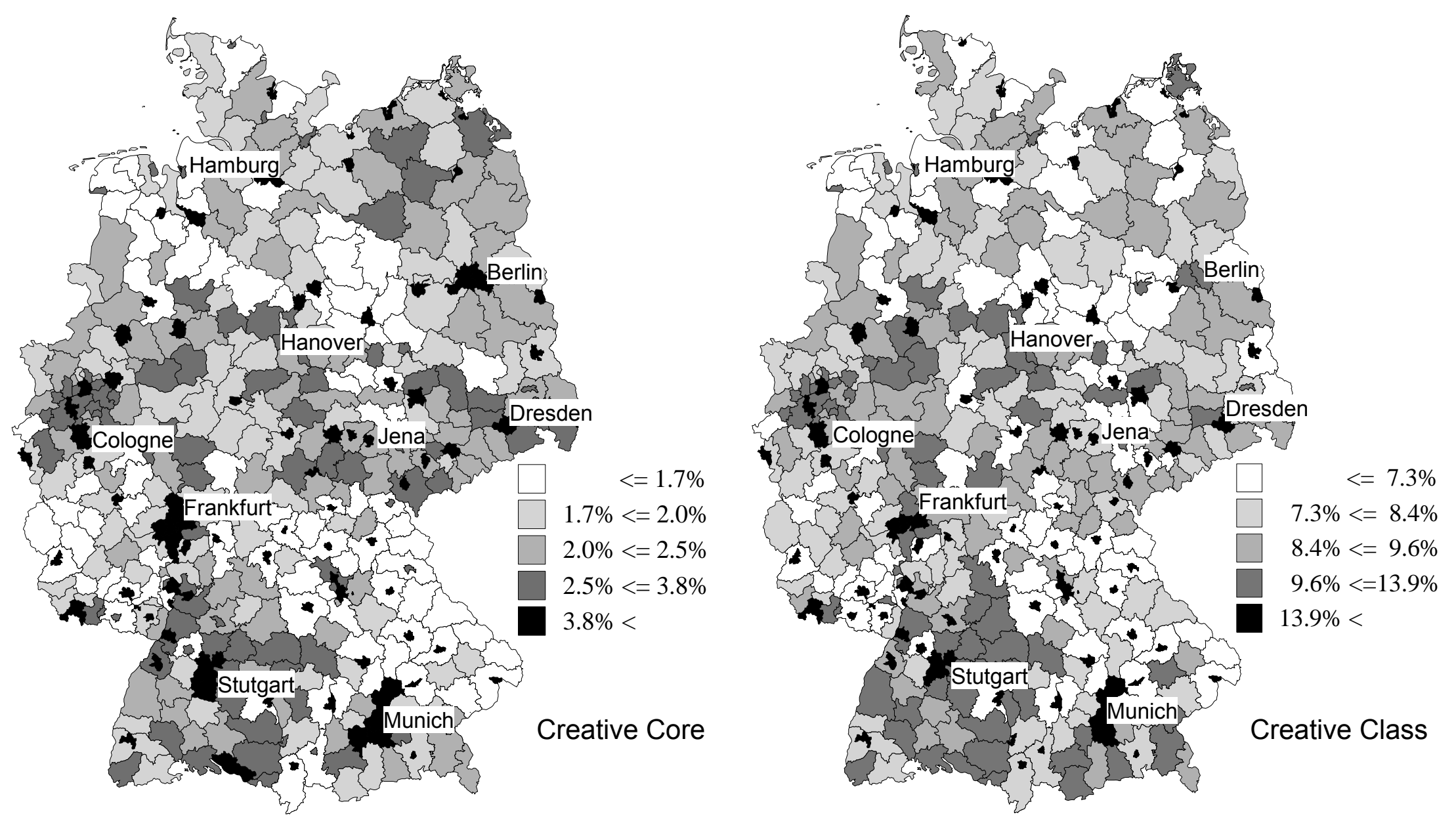

Figure 2: Population share of Creative Core and Creative Class in German districts 2004 
Table 3: Numbers, shares and location coefficients of people in creative occupations in East and West Germany $2004^{a}$

\begin{tabular}{|c|c|c|c|c|}
\hline & West & $\begin{array}{c}\text { East } \\
\text { (including } \\
\text { Berlin) }\end{array}$ & $\begin{array}{c}\text { East } \\
\text { (Berlin } \\
\text { excluded) }\end{array}$ & Berlin \\
\hline \multirow{2}{*}{ Creative class } & $8,029,361$ & $1,936,811$ & $1,453,397$ & 483,414 \\
\hline & $12.3 / 1.02$ & $11.3 / 0.93$ & $10.6 / 0.87$ & $14.3 / 1.18$ \\
\hline \multirow{2}{*}{ Creative core } & $2,080,068$ & 539,055 & 409,685 & 129,370 \\
\hline & $3.2 / 1.00$ & $3.2 / 0.99$ & $3.0 / 0.94$ & $3.8 / 1.20$ \\
\hline \multirow{2}{*}{ Creative professionals } & $5,515,775$ & $1,271,410$ & 979,168 & 292,242 \\
\hline & $8.5 / 1.03$ & $7.4 / 0.90$ & $7.1 / 0.87$ & $8.6 / 1.04$ \\
\hline \multirow{2}{*}{ Employed bohemians } & 276,698 & 77,083 & 47,287 & 29,796 \\
\hline & $0.42 / 0.99$ & $0.45 / 1.05$ & $0.34 / 0.80$ & $0.88 / 2.04$ \\
\hline \multirow{2}{*}{ Freelance artists } & 156,820 & 49,263 & 17,257 & 32,006 \\
\hline & $0.24 / 0.96$ & $0.29 / 1.15$ & $0.13 / 0.50$ & $0.94 / 3.77$ \\
\hline \multirow{2}{*}{ - Writers } & 41,924 & 13,694 & 3,836 & 9,858 \\
\hline & $0.06 / 0.95$ & $0.08 / 1.18$ & $0.03 / 0.41$ & $0.29 / 4.30$ \\
\hline \multirow{2}{*}{ - Performing arts } & 16,694 & 7,140 & 1,984 & 5,156 \\
\hline & $0.03 / 0.88$ & $0.04 / 1.44$ & $0.01 / 0.50$ & $0.15 / 5.24$ \\
\hline \multirow{2}{*}{ - Musicians } & 40,511 & 12,117 & 5,712 & 6,405 \\
\hline & $0.06 / / 0.97$ & $0.07 / 1.11$ & $0.04 / 0.65$ & $0.19 / 2.95$ \\
\hline \multirow{2}{*}{ - Fine arts } & 57,691 & 16,312 & 5,725 & 10,587 \\
\hline & $0.09 / 0.98$ & $0.10 / 1.06$ & $0.04 / 0.46$ & $0.31 / 3.47$ \\
\hline \multirow{2}{*}{$\begin{array}{l}\text { Employees with social } \\
\text { insurance }\end{array}$} & $21,408,773$ & $5,112,201$ & $4,070,008$ & $1,042,193$ \\
\hline & $32.9 / 1.02$ & $29.9 / 0.93$ & $29.7 / 0.92$ & $30.7 / 0.95$ \\
\hline \multirow{2}{*}{ Population } & $65,122,400$ & $17,097,900$ & $13,706,400$ & $3,391,500$ \\
\hline & $79.2^{\mathrm{b}}$ & $20.8^{\mathrm{b}}$ & $16.7^{\mathrm{b}}$ & $4.1^{\mathrm{b}}$ \\
\hline
\end{tabular}

${ }^{a}$ First row: Number of people in the respective category. Second row: percentage share of creative people over population (left) and location coefficient (right).

${ }^{b}$ Percentage share of population in the respective spatial category. 
scattered throughout the cities is that they are assigned to their place of residence while the employed bohemians are assigned to the location of their workplaces, which are concentrated in the cities.

The share of employees in the creative core is also relatively high in the cities (figure 2). However, the cities with the highest share of creative core employees are medium-sized cities such as Erlangen, Darmstadt, Heidelberg, Ulm, Wolfsburg, Regensburg and Jena; many of them have a large manufacturing sector and a headquarter of a large firm. The only larger cities with high shares of creative core employment are Munich and Stuttgart. The population share of the Creative Class as a whole ranges between 40.9 percent (city of Erlangen) and 4.1 percent (Pirmasens). Relatively high shares are found in the cities of Düsseldorf, Frankfurt (Main), Munich and Stuttgart.

In the discussion about the long-lasting economic weakness of the East German economy, it has sometimes been argued that the share of creative people in the East is relatively low because the creative part of the population has migrated outward during the GDR regime and thereafter. The share of the Creative Class is, indeed, 1.0 percent lower in the East as compared to the West (table 3). This result is particularly due to the relatively low share of creative professionals in East Germany. However, the share of the creative core in East Germany is only slightly below the Western level, and the share of employed bohemians and freelance artists is higher in the East than in the West. These results are largely due to a high concentration of people with creative occupations, particularly the employed bohemians and freelance artists, in Berlin. If Berlin is excluded, the location coefficients for the creative people in East Germany are clearly below the West German level. 


\section{What determines the regional share of creative population?}

In order to explain the regional share of creative population three hypotheses are tested:

- First, a high quality of life in a region attracts creative people. I use two indicators for the regional quality of life. One indicator is the abundance and the variety of the cultural supply in a region as measured by the share of employed bohemians and freelance artists (Artist-Bohemian Index). A second indicator is the share of the employees in public health care and education (Public Provision Index).

- Second, creative people value a regional environment that is characterized by openness and tolerance. The measure for openness and tolerance is the share of people with foreign citizenship living in a region (Openness Index). This indicator corresponds to Florida's (2004) Melting-Pot Index.

- Third, job opportunities on the regional labor market are relatively unimportant for the locational choice of the creative people. Regional opportunities of employment are measured by the average employment growth rate in the preceding three and seven years.

Population density is included in the regressions as a catch-all variable to control for all kinds of regional characteristics such as land prices, size of the labor market and availability of public infrastructure. In order to account for the special situation in East Germany, a dummy variable for a location in the East (including Berlin; 1=East, $0=$ West) is entered into the regressions. Since the share of population with foreign citizenship is generally lower in the East, I also include an interaction of the dummy for a location in East Germany with the Openness Index. In order to facilitate a comparison of the different independent variables, the tables show the standardized regression coefficients (beta coefficients). The higher the absolute value of a beta coefficient, the stronger the impact of the 
respective variable on the share of creative people is. Table A1 in the Appendix shows descriptive statistics for the variables included in the regressions.

The regressions for the share of creative class and the creative core (tables 4 and 5) clearly indicate a positive impact on the share of employed bohemians and the freelance artists. A slightly larger positive effect can also be found for the Public Provision Index and the Openness Index. While population density is not statistically significant, the dummy for location in East Germany has a significantly positive value indicating a relatively high share of creative employment in the East. The negative sign for the interaction of location in East Germany and the Openness

Table 4: Determinants of the regional share of Creative Class 2004 (without bohemians) $^{a}$

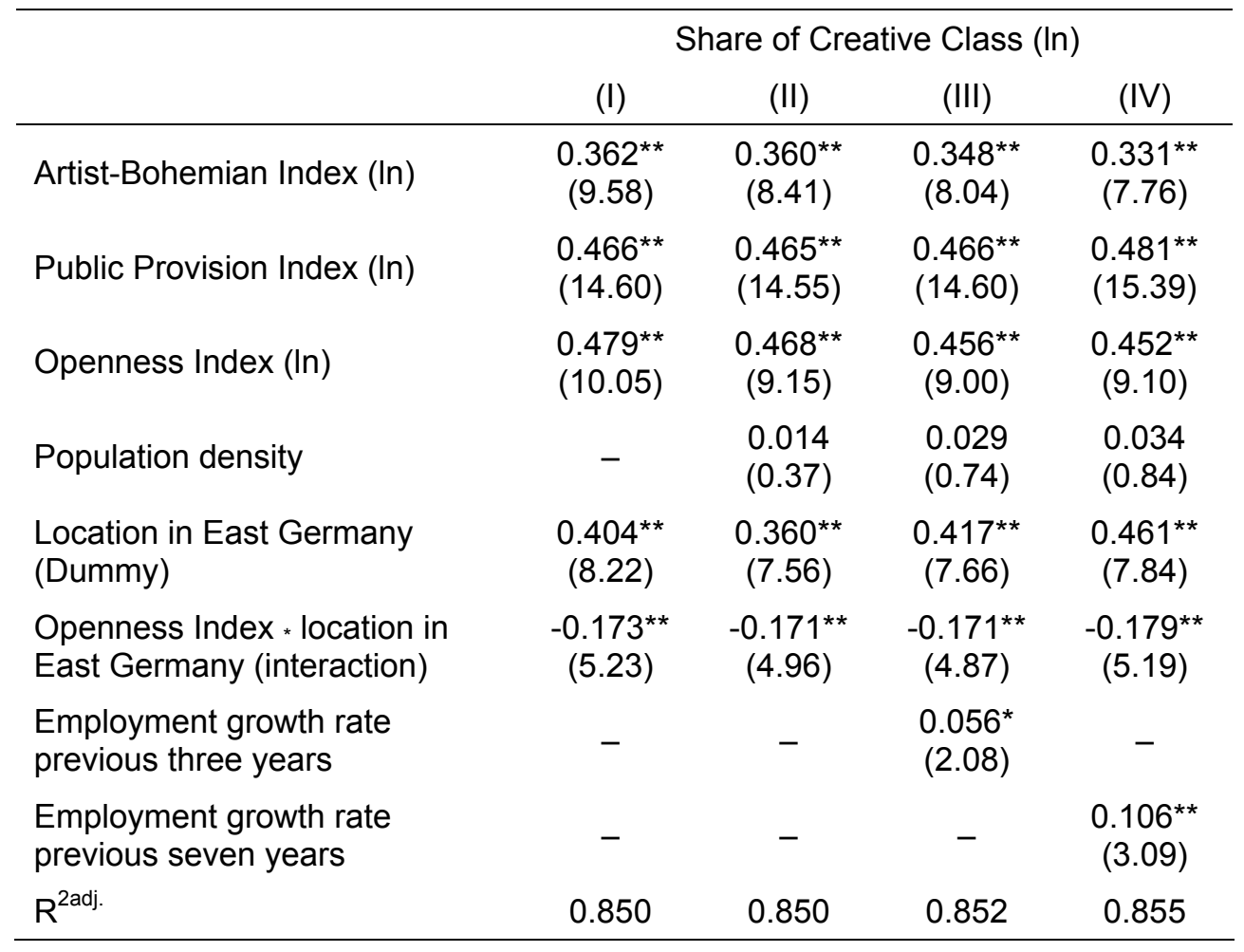

${ }^{a}$ Beta coefficients of robust least square regressions; $t$-values in parentheses;

${ }^{* *}$ statistically significant at the 1 percent level, ${ }^{*}$ statistically significant at the five percent level; number of observations: 438. 
Index show that the positive effect of the population with foreign citizenship is considerably weaker in the East. The effect of employment growth on the share of creative people in a region turns out to be relatively weak as compared to the results for the other variables. The higher beta coefficient for the seven-year employment growth rate indicates that the effect of employment opportunities is particularly relevant in the long run. It can be concluded from these results that creative people do not completely ignore their employment opportunities on the local labor market and that they do tend to follow jobs, but that the effect is relatively small as compared to other characteristics of a region.

Table 5: Determinants of the regional share of Creative Core $2004^{a}$

\begin{tabular}{lcccc}
\hline & \multicolumn{5}{c}{ Share of creative core population (In) } \\
& $(\mathrm{I})$ & $(\mathrm{II})$ & $(\mathrm{III})$ & $(\mathrm{IV})$ \\
\hline \multirow{2}{*}{ Artist-Bohemian Index $(\mathrm{In})$} & $0.348^{* *}$ & $0.351^{* *}$ & $0.344^{* *}$ & $0.324^{* *}$ \\
& $(8.59)$ & $(7.55)$ & $(7.37)$ & $(7.09)$ \\
Public Provision Index (In) & $0.412^{* *}$ & $0.412^{* *}$ & $0.414^{* *}$ & $0.428^{* *}$ \\
& $(12.35)$ & $(12.57)$ & $(12.55)$ & $(13.27)$ \\
Openness Index (In) & $0.592^{* *}$ & $0.598^{* *}$ & $0.590^{* *}$ & $0.583^{* *}$ \\
& $(11.40)$ & $(10.26)$ & $(10.18)$ & $(10.22)$ \\
Population density & - & -0.009 & 0.001 & 0.010 \\
& & $(0.22)$ & $(0.03)$ & $(0.27)$ \\
Location in East Germany & $0.658^{* *}$ & $0.663^{* *}$ & $0.677^{* *}$ & $0.727^{* *}$ \\
(Dummy) & $(12.25)$ & $(11.12)$ & $(10.98)$ & $(11.12)$ \\
Openness Index * location in & $-0.202^{* *}$ & $-0.203^{* *}$ & $-0.203^{* *}$ & $-0.211^{* *}$ \\
East Germany (interaction) & $(5.73)$ & $(5.61)$ & $(5.54)$ & $(5.86)$ \\
Employment growth rate & & & 0.038 & - \\
previous three years & - & - & $(1.29)$ & - \\
Employment growth rate & & & & $0.105^{* *}$ \\
previous seven years & - & - & - & $(2.77)$ \\
$R^{\text {2adj. }}$ & 0.831 & 0.831 & 0.836 & 0.836 \\
\hline
\end{tabular}

${ }^{a}$ Beta coefficients of robust least square regressions; $t$-values in parentheses; ** statistically significant at the 1 percent level, * statistically significant at the five percent level; number of observations: 438. 
Table 6: Determinants of the regional share of employed bohemians 2004

\begin{tabular}{|c|c|c|c|c|}
\hline & \multicolumn{4}{|c|}{ Share of employed bohemians (In) } \\
\hline & $(\mathrm{l})$ & (II) & (III) & (IV) \\
\hline Public Provision Index (In) & $\begin{array}{l}0.496^{* *} \\
(14.46)\end{array}$ & $\begin{array}{l}0.446^{* *} \\
(12.06)\end{array}$ & $\begin{array}{l}0.444^{* *} \\
(11.96)\end{array}$ & $\begin{array}{l}0.455^{* *} \\
(12.31)\end{array}$ \\
\hline Openness Index (In) & $\begin{array}{l}0.778^{* *} \\
(13.45)\end{array}$ & $\begin{array}{l}0.538^{\star *} \\
(7.29)\end{array}$ & $\begin{array}{l}0.518^{* *} \\
(7.12)\end{array}$ & $\begin{array}{r}0.497^{* *} \\
(6.91)\end{array}$ \\
\hline Population density & - & $\begin{array}{l}0.239^{* *} \\
(4.17)\end{array}$ & $\begin{array}{l}0.252^{* *} \\
(4.42)\end{array}$ & $\begin{array}{c}0.256^{* *} \\
(4.32)\end{array}$ \\
\hline $\begin{array}{l}\text { Location in East Germany } \\
\text { (Dummy) }\end{array}$ & $\begin{array}{l}0.612^{* *} \\
(8.22)\end{array}$ & $\begin{array}{l}0.444^{* *} \\
(5.86)\end{array}$ & $\begin{array}{l}0.466^{* *} \\
(5.96)\end{array}$ & $\begin{array}{r}0.526^{* *} \\
(6.45)\end{array}$ \\
\hline $\begin{array}{l}\text { Openness Index * location in } \\
\text { East Germany (interaction) }\end{array}$ & $\begin{array}{l}-0.102 \\
(1.88)\end{array}$ & $\begin{array}{l}-0.075 \\
(1.45)\end{array}$ & $\begin{array}{l}-0.075 \\
(1.45)\end{array}$ & $\begin{array}{l}-0.087 \\
(1.69)\end{array}$ \\
\hline $\begin{array}{l}\text { Employment growth rate } \\
\text { previous three years }\end{array}$ & - & - & $\begin{array}{l}0.062 \\
(1.75)\end{array}$ & - \\
\hline $\begin{array}{l}\text { Employment growth rate } \\
\text { previous seven years }\end{array}$ & - & - & - & $\begin{array}{l}0.146^{* *} \\
(3.24)\end{array}$ \\
\hline $\mathrm{R}^{2 \mathrm{adj}}$ & 0.663 & 0.689 & 0.692 & 0.699 \\
\hline
\end{tabular}

${ }^{\text {a }}$ Beta coefficients of robust least square regressions; $t$-values in parentheses; * * statistically significant at the 1 percent level, ${ }^{*}$ statistically significant at the five percent level; number of observations: 438.

The analyses for the share of employed bohemians (table 6) show a rather strong positive effect for the Public Provision Index and the Openness Index. The positive effect of the population density is probably due to a concentration of cultural establishments such as theaters, opera houses etc. in larger cities. The significantly positive coefficient for the East-Germany dummy may also be an effect of relatively high numbers of cultural establishments in the East. Again, there is only a relatively weak influence for the employment growth rate.

In the regressions for the share of freelance artists (table 7), the effect of the Public Provision Index is much weaker than for the employed bohemians. The dummy variable for location in East Germany 
Table 7: Determinants of the regional share of freelance artists $2004^{a}$

\begin{tabular}{|c|c|c|c|c|}
\hline & \multicolumn{4}{|c|}{ Share of freelance artists (In) } \\
\hline & (I) & (II) & (III) & (IV) \\
\hline Public Provision Index (In) & $\begin{array}{l}0.132^{* *} \\
(3.13)\end{array}$ & $\begin{array}{l}0.086 \\
(1.92)\end{array}$ & $\begin{array}{l}0.081 \\
(1.84)\end{array}$ & $\begin{array}{l}0.010^{*} \\
(2.21)\end{array}$ \\
\hline Openness Index (In) & $\begin{array}{l}0.619^{* *} \\
(8.15)\end{array}$ & $\begin{array}{l}0.394^{* *} \\
(4.51)\end{array}$ & $\begin{array}{l}0.357^{* *} \\
(4.07)\end{array}$ & $\begin{array}{c}0.338^{* * *} \\
(3.82)\end{array}$ \\
\hline Population density & - & $\begin{array}{l}0.223^{* *} \\
(2.95)\end{array}$ & $\begin{array}{l}0.249^{* *} \\
(3.27)\end{array}$ & $\begin{array}{c}0.247^{* *} \\
(3.19)\end{array}$ \\
\hline $\begin{array}{l}\text { Location in East Germany } \\
\text { (Dummy) }\end{array}$ & $\begin{array}{l}-0.013 \\
(0.14)\end{array}$ & $\begin{array}{l}-0.170 \\
(1.80)\end{array}$ & $\begin{array}{l}-0.129 \\
(1.37)\end{array}$ & $\begin{array}{l}-0.057 \\
(0.58)\end{array}$ \\
\hline $\begin{array}{l}\text { Openness Index * location in } \\
\text { East Germany (interaction) }\end{array}$ & $\begin{array}{l}0.113 \\
(1.37)\end{array}$ & $\begin{array}{l}0.137^{*} \\
(2.07)\end{array}$ & $\begin{array}{l}0.138^{*} \\
(2.15)\end{array}$ & $\begin{array}{l}0.121 \\
(1.87)\end{array}$ \\
\hline $\begin{array}{l}\text { Employment growth rate } \\
\text { previous three years }\end{array}$ & - & - & $\begin{array}{l}0.122^{* *} \\
(2.73)\end{array}$ & - \\
\hline $\begin{array}{l}\text { Employment growth rate } \\
\text { previous seven years }\end{array}$ & - & - & - & $\begin{array}{l}0.203^{* *} \\
(2.72)\end{array}$ \\
\hline $\mathrm{R}^{2 \mathrm{adj}}$ & 0.410 & 0.433 & 0.444 & 0.453 \\
\hline
\end{tabular}

${ }^{a}$ Beta coefficients of robust least square regressions; $t$-values in parentheses; ** statistically significant at the 1 percent level, ${ }^{*}$ statistically significant at the five percent level; number of observations: 438.

is insignificant and the interaction between the East dummy and the Openness Index has a positive sign. The effect of short- and mediumterm employment growth on the population share of the freelance artists is more pronounced than for the other types of creative people. This indicates a somewhat higher dependence on regional prosperity.

\section{Is creative population in a region related to innovation, entrepreneurship and growth?}

As a simple test of Richard Florida's conjecture that "cultural creativity," "technological creativity" (= invention and innovation) and "economic creativity" (= entrepreneurship) are related (see section 2), rankcorrelation coefficients for the relationship of respective indicators have been calculated. For this type of analysis, the 438 German districts have been aggregated to the more comprehensive planning regions which are 
better suited for an analysis of economic development. ${ }^{7}$ Planning regions include at least one core city as well as its surroundings. ${ }^{8}$ Since the definition of planning regions focuses on commuter distances, they represent functional spatial economic entities in the sense of travel to work areas. Because there is strong indication that the eastern part of the country, the former German Democratic Republic, is more characterized by a distinct growth regime than Western Germany (cf. Fritsch, 2004) the analysis has been carried out for the both parts of the country separately.

There is a considerable degree of correlation between the share of persons in creative occupations and the share of employed persons with tertiary degree (table A2 in the Appendix). While the statistical relationship between the employment share in R\&D intensive manufacturing industries and the share of employees with tertiary degree is positive, the correlation coefficients of R\&D intensive manufacturing employment with the creative class indicators are in nearly all cases insignificant or even significantly negative (table 8 )..$^{9}$ There is, however, a

\footnotetext{
${ }^{7}$ Such an aggregation of districts to planning regions is, for example, appropriate if new businesses are set up in an adjacent district. It is particularly important when patents are included in the analysis. Patents are assigned to the residence of the inventor (see Greif and Schmiedl, 2002). Since many of the inventors work in the inner cities but live in surrounding areas, the number of patents in the cities would be systematically underestimated in an analysis at the district level.

8 For the definition of the planning regions see the Federal Office for Building and Regional Planning (Bundesamt für Bauwesen und Raumordnung, BBR) (2003). For historical reasons, the cities of Berlin, Hamburg and Bremen are defined as planning regions even though they are not functional economic units. In order to create functional units, these cities have been merged with adjacent planning regions for the analysis. Berlin was merged with the region Havelland-Flaeming, Hamburg was merged with the region Schleswig-Holstein South, Bremen with Bremerhaven and with the region Bremen-Umland. Due to changes in the definition of the region during the period of analysis, the Berlin region had to be excluded.

${ }^{9} \mathrm{R} \& \mathrm{D}$ intensive manufacturing and knowledge-intensive service industries are characterized by a high share of employment with a tertiary degree in engineering and the natural sciences. For a detailed description of this classification see Grupp and Legler (2000). One might suspect that the weak correspondence of creative class and employment in $R \& D$ intensive manufacturing could be caused by the relatively low
} 
pronounced positive relationship between creative occupations and the share of employment in knowledge intensive services. This indicates that the share of creative occupations tends to be relatively high in regions with a concentration in knowledge intensive services rather than in regions with large proportions of employment in $R \& D$ intensive manufacturing. A distinct positive statistical relationship can be found between the share of the different categories of creative employment and the regional level of new business formation. This holds for the start-ups in all private sector industries as well as for the start-ups in R\&D intensive manufacturing and in knowledge intensive services. ${ }^{10} \mathrm{~A}$ strong positive relationship with the start-up rate for different sector definitions is also found for the share of employees with a tertiary degree, thus, indicating the importance of qualification and knowledge for the formation of new and innovative businesses. The number of patents per 1,000 population stands for the technological creativity in a region. ${ }^{11}$ There is a positive relationship of this measure with the share of employees in creative occupations as well as with the share of employees with a tertiary degree. It is quite remarkable that these correlation coefficients are considerably higher in the eastern part of the country, thereby

share of manufacturing industries in high-density agglomerations where the share of creative class occupations tends to be comparatively high (see section 4 and 5 ). However, in a multivariate setting with a control for population density, the results are essentially the same. The pronounced positive relationship between the creative class indicators and employment in knowledge intensive services also remains about the same if population density is controlled.

${ }^{10}$ The start-up rate is defined as the number of start-ups per 1,000 population. The data on start-ups are from the Foundation Panels of the Centre for European Economic Research (ZEW-Mannheim). For a description of this data source see Almus, Engel and Prantl (2000). I am greatly indebted to the ZEW for making these data available.

${ }^{11}$ The information on patents is for the years 1995-2000 and was taken from Greif and Schmiedl (2002). Since creative processes require some time until they lead to a patentable idea, a time lag of three years between the creativity and education indicators and the patents per resident population was assumed here. 
Table 8: Rank correlations between regional employment shares of different types of creative occupation, share of employees with a tertiary degree and indicators for regional innovativeness and entrepreneurship in East and in West Germany

\begin{tabular}{|c|c|c|c|c|}
\hline & $\begin{array}{l}\text { Share of } \\
\text { employees } \\
\text { with a } \\
\text { tertiary } \\
\text { degree }\end{array}$ & $\begin{array}{l}\text { Share of } \\
\text { creative } \\
\text { core }\end{array}$ & $\begin{array}{l}\text { Share of } \\
\text { creative } \\
\text { professionals }\end{array}$ & $\begin{array}{l}\text { Share of } \\
\text { employed } \\
\text { bohemians }\end{array}$ \\
\hline & \multicolumn{4}{|c|}{ West Germany } \\
\hline \multicolumn{5}{|l|}{$\begin{array}{l}\text { Share of employees } \\
\text { in: }^{a}\end{array}$} \\
\hline $\begin{array}{l}\text { - R\&D intensive } \\
\text { manufacturing }\end{array}$ & $0.179^{* *}$ & 0.002 & $-0.347^{* *}$ & $-0.197^{\star *}$ \\
\hline $\begin{array}{l}\text { - knowledge } \\
\text { intensive services }\end{array}$ & $0.629^{* *}$ & $0.506^{* *}$ & $0.267^{* *}$ & $0.311^{* *}$ \\
\hline \multicolumn{5}{|l|}{ Start-up rate ${ }^{b}$} \\
\hline - overall & $0.682^{* *}$ & $0.578^{* *}$ & $0.510^{* *}$ & $0.614^{* *}$ \\
\hline $\begin{array}{l}\text { - R\&D intensive } \\
\text { manufacturing }\end{array}$ & $0.572^{* *}$ & $0.438^{* *}$ & $0.276^{* *}$ & $0.466^{* *}$ \\
\hline $\begin{array}{l}\text { - } \text { knowledge } \\
\text { intensive services }\end{array}$ & $0.747^{* *}$ & $0.648^{* *}$ & $0.585^{\star *}$ & $0.691^{* *}$ \\
\hline \multirow[t]{2}{*}{$\begin{array}{l}\text { Patents per } 1,000 \\
\text { population }^{c}\end{array}$} & $0.429^{* *}$ & $0.290^{* *}$ & 0.060 & 0.099 \\
\hline & \multicolumn{4}{|c|}{ East Germany } \\
\hline \multicolumn{5}{|l|}{$\begin{array}{l}\text { Share of employees } \\
\text { in: }^{a}\end{array}$} \\
\hline $\begin{array}{l}\text { - R\&D intensive } \\
\text { manufacturing }\end{array}$ & $0.478^{* *}$ & 0.101 & -0.031 & $0.225^{* *}$ \\
\hline $\begin{array}{l}\text { - knowledge } \\
\text { intensive services }\end{array}$ & $0.699^{* *}$ & $0.555^{* *}$ & $0.504^{* *}$ & $0.735^{* *}$ \\
\hline \multicolumn{5}{|l|}{ Start-up rate ${ }^{\mathrm{b}}$} \\
\hline - overall & $0.680^{* *}$ & $0.272^{* *}$ & $0.492^{* *}$ & $0.706^{* *}$ \\
\hline $\begin{array}{l}\text { - R\&D intensive } \\
\text { manufacturing }\end{array}$ & $0.610^{* *}$ & $0.319^{* *}$ & $0.354^{* *}$ & $0.659^{* *}$ \\
\hline $\begin{array}{l}\text { - knowledge } \\
\text { intensive services }\end{array}$ & $0.722^{\star *}$ & $0.353^{* *}$ & $0.578^{* *}$ & $0.744^{* *}$ \\
\hline $\begin{array}{l}\text { Patents per } 1,000 \\
\text { population }^{c}\end{array}$ & $0.788^{* *}$ & $0.627^{* *}$ & $0.584^{* *}$ & $0.689^{* *}$ \\
\hline
\end{tabular}

Notes: Years of observation vary due to data availability. ${ }^{\text {a }}$ Data for the years $1998-2004$ (West Germany 426 cases; East Germany 154 cases). ${ }^{b}$ Pooled data for the years 1990-2004 (West Germany, 923 cases) and 1993-2004 (East Germany 160 cases). ${ }^{c}$ Data for the years 1993-2000 (West Germany 426 cases; East Germany 110 cases. ** statistically significant at the 1 percent level: ${ }^{*}$ statistically significant at the five percent level. 
indicating differences in the innovation systems and growth regimes in the two parts of the country. ${ }^{12}$ All in all, these correlations can be regarded as a confirmation of Richard Florida's conjecture that there is a positive relationship between cultural, economics and technological creativity.

For assessing the effect of the share of creative people and employment change in the subsequent years, panel regressions with fixed effects have been estimated. The dependent variable was the percent of the employment change over a five year period. The share of employees with a tertiary degree and the shares of persons in creative occupations at the beginning of this five year period have been included as explanatory variables. ${ }^{13}$ For West Germany, the data cover the 19872004 period; the analysis for the East German regions is for the years 1996-2004. Descriptive statistics for the variables are provided in table A3 in the Appendix. In the estimations for West Germany, we find a negative effect of the share of employees with a tertiary degree if this indicator is the only explanatory variable in the model (model I in table 10). In a model (model II) that contains only the share of the creative class, the respective coefficient also has a negative sign that is probably due to the high correlation of this variable with the share of employees with a tertiary degree. Including the qualification variable and the creativity indices into one model (model III to VII), thus, results in a positive impact of creativity on employment growth and a negative effect

\footnotetext{
${ }^{12}$ Empirical analyses of innovation activity in the two parts of the country do indeed show pronounced differences between East and West Germany (Fritsch and Slavtchev, 2006, 2007). In particular, the number of patents per R\&D employee is much lower in East Germany.

${ }^{13}$ The information on the number of freelance bohemians was only available for two recent years (2004 and 2005) and could not be used for explaining employment change in earlier periods.
} 
Table 10: The relationship between qualification of regional labor force, creative occupations and regional employment change - fixed effects panel regressions

\begin{tabular}{|c|c|c|c|c|c|c|c|}
\hline & $\mathrm{I}$ & II & III & IV & V & $\mathrm{VI}$ & VII \\
\hline & \multicolumn{7}{|c|}{ West Germany } \\
\hline $\begin{array}{l}\text { Share of } \\
\text { employees with a } \\
\text { tertiary degree }(\ln )\end{array}$ & $\begin{array}{l}-15.585^{\star \star} \\
(14.19)\end{array}$ & - & $\begin{array}{c}-54.959^{* *} \\
(12.11)\end{array}$ & $\begin{array}{c}-25.577^{* *} \\
(4.07)\end{array}$ & $\begin{array}{c}-36.387^{* *} \\
(12.42)\end{array}$ & $\begin{array}{c}-21.962^{\star *} \\
(13.42)\end{array}$ & $\begin{array}{c}-70.980^{* *} \\
(11.34)\end{array}$ \\
\hline $\begin{array}{l}\text { Share of creative } \\
\text { class A (without } \\
\text { bohemians) (In) }\end{array}$ & - & $\begin{array}{c}-30.983^{\star *} \\
(11.43)\end{array}$ & $\begin{array}{c}96.517^{* *} \\
(8.92)\end{array}$ & - & - & - & - \\
\hline $\begin{array}{l}\text { Share of creative } \\
\text { core }(\ln )\end{array}$ & - & - & - & $\begin{array}{c}10.780 \\
(1.61)\end{array}$ & - & - & - \\
\hline $\begin{array}{l}\text { Share of creative } \\
\text { professionals (In) }\end{array}$ & - & - & - & - & $\begin{array}{c}74.396^{* *} \\
(7.62)\end{array}$ & - & - \\
\hline $\begin{array}{l}\text { Share of employed } \\
\text { bohemians (In) }\end{array}$ & - & - & - & - & - & $\begin{array}{c}15.676^{* *} \\
(5.19)\end{array}$ & - \\
\hline $\begin{array}{l}\text { Share of creative } \\
\text { class B (including } \\
\text { bohemians) (In) }\end{array}$ & - & - & - & - & - & - & $\begin{array}{c}126.042^{* *} \\
(8.41)\end{array}$ \\
\hline Constant & $\begin{array}{c}125.739^{* *} \\
(75.13)\end{array}$ & $\begin{array}{c}206.752^{* *} \\
(22.57)\end{array}$ & $\begin{array}{c}-140.546^{* *} \\
(4.70)\end{array}$ & $\begin{array}{c}{ }^{*} 121.836^{* *} \\
(41.45)\end{array}$ & $\begin{array}{c}-77.033^{* *} \\
(2.89)\end{array}$ & $\begin{array}{c}139.785^{* *} \\
(44.11)\end{array}$ & $\begin{array}{c}216.798^{* *} \\
(5.21)\end{array}$ \\
\hline $\mathrm{R}^{2}$ & 0.191 & 0.133 & 0.261 & 0.194 & 0.243 & 0.216 & 0.210 \\
\hline \multirow[t]{2}{*}{$\mathrm{F}$ value } & $4.85^{\star *}$ & $4.71^{* *}$ & $7.50^{* *}$ & $5.69^{* *}$ & $7.06^{* *}$ & $6.17^{* *}$ & $9.03^{* *}$ \\
\hline & \multicolumn{7}{|c|}{ East Germany } \\
\hline $\begin{array}{l}\text { Share of } \\
\text { employees with a } \\
\text { tertiary degree }(\ln )\end{array}$ & $\begin{array}{c}40.962^{* *} \\
(5.37)\end{array}$ & - & $\begin{array}{c}41.336^{\star *} \\
(5.47)\end{array}$ & $\begin{array}{c}39.729^{* *} \\
(5.40)\end{array}$ & $\begin{array}{c}40.712^{* *} \\
(5.82)\end{array}$ & $\begin{array}{c}30.704^{\star \star} \\
(3.61)\end{array}$ & $\begin{array}{c}40.746^{* *} \\
(5.41)\end{array}$ \\
\hline $\begin{array}{l}\text { Share of creative } \\
\text { class A (without } \\
\text { bohemians) (In) }\end{array}$ & - & $\begin{array}{c}-51.910^{* *} \\
(9.32)\end{array}$ & $\begin{array}{c}-23.090^{* *} \\
(1.52)\end{array}$ & - & - & - & - \\
\hline $\begin{array}{l}\text { Share of creative } \\
\text { core (In) }\end{array}$ & - & - & - & $\begin{array}{l}-15.848^{*} \\
(2.43)\end{array}$ & - & - & - \\
\hline $\begin{array}{l}\text { Share of creative } \\
\text { professionals (In) }\end{array}$ & - & - & - & - & $\begin{array}{l}6.875 \\
(0.37)\end{array}$ & - & - \\
\hline $\begin{array}{l}\text { Share of employed } \\
\text { bohemians (In) }\end{array}$ & - & - & - & - & - & $\begin{array}{c}-10.137^{*} \\
(2.41)\end{array}$ & - \\
\hline $\begin{array}{l}\text { Share of creative } \\
\text { class B (including } \\
\text { bohemians) (In) }\end{array}$ & - & - & - & - & - & - & $\begin{array}{c}-24.217 \\
(1.64)\end{array}$ \\
\hline Constant & $\begin{array}{c}-101.447^{* *} \\
(6.13)\end{array}$ & $\begin{array}{c}161.221 \\
(8.78)\end{array}$ & $\begin{array}{c}-22.671 \\
(0.42)\end{array}$ & $\begin{array}{c}-64.517^{\star *} \\
(2.93)\end{array}$ & $\begin{array}{c}-122.343^{*} \\
(2.06)\end{array}$ & $\begin{array}{c}-80.673^{* *} \\
(4.45)\end{array}$ & $\begin{array}{c}-16.835 \\
(0.31)\end{array}$ \\
\hline $\mathrm{R}^{2}$ & 0.317 & 0.410 & 0.342 & 0.338 & 0.319 & 0.377 & 0.346 \\
\hline$F$ value & $28.81^{* *}$ & $86.85^{* *}$ & 15.86 & $18.51^{* *}$ & $14.27^{\star *}$ & $18.42^{\star *}$ & $16.15^{* *}$ \\
\hline
\end{tabular}

Notes: Data for West Germany relate to the 1987-1999 period (923 observations). Data for East Germany are for the 1996-1999 period (84 observations). Regional employment change covers the period until 2004. T-values in parentheses; ${ }^{* *}$ statistically significant at the 1 percent level: * statistically significant at the five percent level. 
of qualification. ${ }^{14}$ Obviously, the indicators for qualification and creativity stand for different determinants of growth. In East Germany, however, the share of employees with a tertiary degree assumes a positive sign while the effect of employment in creative occupations is negative. This clearly indicates that the two parts of the country are characterized by distinct types of growth regimes in the period of analysis in which the role of creative occupations differs (Fritsch, 2004).

The results of these fixed-effects panel regressions have two important implications. First, they show rather clearly that an occupation is not just another measure of qualification but that there are important differences between these two issues. Second, the different pattern of influences in East and West Germany signify that the effect of the creative class on economic development depends on the regional or national framework conditions. Hence, promoting the creative class may not be recommended as a general strategy under all types of circumstances.

\section{Summary and conclusion}

Richard Florida (2004) has argued that creative people prefer to live in regions that are characterized by ethnical and cultural diversity as well as by a high level of public spending on education and health care. He also suggests that creative people show only a weak tendency to leave such an environment for jobs but that they tend to draw new jobs into a region ('jobs follow people'). Furthermore, Florida supposes that cultural, economic as well as technological creativity are positively

\footnotetext{
${ }^{14}$ The same pattern shows if the analysis for West Germany is restricted to the same time period as the regressions for East Germany. If employment change over a ten year period is used as a dependent variable, the $R^{2}$-values are considerably lower than with the five year employment change but the results are essentially the same as for the five year employment change.
} 
related and that a high share of creative people in a region corresponds to a high level of innovation, entrepreneurship and growth.

Based on data for German regions, some confirmation of these hypotheses could be found. There are, indeed, indications in the data that creative people prefer to live in locations with high levels of ethnical diversity, cultural activity as well as public spending on education and health care. The analyses, however, also suggest that creative people do not completely ignore the labor market opportunities in their choice of location and do follow jobs - but only to a certain degree. There is also a positive empirical relationship between creative people, innovation, entrepreneurship and regional growth. In multivariate analyses with workforce qualification and creative occupations as explanatory variables for regional development, the two types of variables had quite different effects, thus, indicating that they represent distinct determinants of growth. The differences in the results between East and West Germany indicate that the effects of the creative class may not be identical in all regions but can critically depend on the characteristics of the respective regional growth regime. Further careful analysis is necessary in order to identify and to understand the relevant relationships.

A critical issue that is of crucial importance for the empirical study of the effect of creativity on regional development is the identification of creative people. Creativity of people can hardly be assessed directly and is not a characteristic that is reported in official statistics. Therefore, Florida's approach of measuring the immeasurable by identifying the creative class by occupation cannot be regarded as more than a rather rough approximation. The creative class, according to this definition, is a rather heterogeneous crowd. It includes people of different ages and stages of their career; scientists, engineers, highly paid managers as well as poor artists without a regular income. These people may have 
rather different preferences as well as degrees of freedom in making locational choices. The basic idea that creativity and knowledge constitute key drivers of regional development and that policy should account for people who embody these important resources has great appeal. Yet, we need to know considerably more about these types of people and their role in the local social system in order to be able to draw substantiated policy conclusions. 


\section{Appendix}

Table A1: Descriptive statistics for the distribution of the variables used in the regressions for the share of creative occupations (table 4- table 7)

\begin{tabular}{|c|c|c|c|c|}
\hline Variable & Mean & $\begin{array}{l}\text { Standard } \\
\text { deviation }\end{array}$ & Minimum & Maximum \\
\hline $\begin{array}{l}\text { Index creative class } \\
\text { (without bohemians) }\end{array}$ & 10.56 & 5.04 & 4.08 & 39.98 \\
\hline Index creative core & 2.83 & 1.79 & 0.70 & 16.68 \\
\hline $\begin{array}{l}\text { Index employed } \\
\text { bohemians }\end{array}$ & 0.32 & 0.40 & 0.04 & 4.78 \\
\hline Index Freelance Artists & 0.17 & 0.14 & 0.03 & 1.11 \\
\hline Artist-Bohemian Index & 0.49 & 0.50 & 0.12 & 5.23 \\
\hline Public Provision Index & 5.08 & 2.34 & 1.13 & 16.37 \\
\hline Openness Index & 6.97 & 4.79 & 0.73 & 26.83 \\
\hline Population density & 509.73 & 655.91 & 40.05 & 3895.50 \\
\hline $\begin{array}{l}\text { Employment growth } \\
\text { rate previous three } \\
\text { years }\end{array}$ & -4.82 & 3.82 & -17.52 & 6.78 \\
\hline $\begin{array}{l}\text { Employment growth } \\
\text { rate previous seven } \\
\text { years }\end{array}$ & -3.79 & 9.99 & -57.25 & 30.35 \\
\hline
\end{tabular}


Table A2: Rank correlations between regional employment shares of different types of creative occupation and qualification in East (lower left part) and in West Germany (upper right part) ${ }^{a}$

\begin{tabular}{|c|c|c|c|c|c|c|}
\hline & $\begin{array}{l}\text { Share of } \\
\text { employees } \\
\text { with a } \\
\text { tertiary } \\
\text { degree }\end{array}$ & $\begin{array}{l}\text { Share } \\
\text { of } \\
\text { creative } \\
\text { core }\end{array}$ & $\begin{array}{l}\text { Share of } \\
\text { creative } \\
\text { professionals }\end{array}$ & $\begin{array}{l}\text { Share of } \\
\text { creative } \\
\text { class A } \\
\text { (without } \\
\text { bohemians) }\end{array}$ & $\begin{array}{l}\text { Share of } \\
\text { employed } \\
\text { bohemians }\end{array}$ & $\begin{array}{l}\text { Share of } \\
\text { creative } \\
\text { class B } \\
\text { (including } \\
\text { bohemians) }\end{array}$ \\
\hline $\begin{array}{l}\text { Share of } \\
\text { employees } \\
\text { with a } \\
\text { tertiary } \\
\text { degree } \\
\text { Share of } \\
\text { creative core }\end{array}$ & 0.520 & 0.933 & 0.685 & 0.858 & 0.783 & 0.867 \\
\hline $\begin{array}{l}\text { Share of } \\
\text { creative } \\
\text { professionals }\end{array}$ & 0.481 & 0.538 & - & 0.937 & 0.680 & 0.934 \\
\hline $\begin{array}{l}\text { Share of } \\
\text { creative } \\
\text { class A } \\
\text { (without } \\
\text { bohemians) }\end{array}$ & 0.566 & 0.901 & 0.826 & - & 0.759 & 0.999 \\
\hline $\begin{array}{l}\text { Share of } \\
\text { employed } \\
\text { bohemians }\end{array}$ & 0.638 & 0.588 & 0.568 & 0.624 & - & 0.789 \\
\hline $\begin{array}{l}\text { Share of } \\
\text { creative } \\
\text { class B } \\
\text { (including } \\
\text { bohemians) }\end{array}$ & 0.581 & 0.897 & 0.826 & 0.997 & 0.672 & - \\
\hline
\end{tabular}

Notes: Data for West Germany are for the years 1987-2004 (1,136 cases). Data for East Germany are for the 1996-2004 period (147 cases). All coefficients are statistically significant at the 1 percent level. 
Table A3: Descriptive statistics for the distribution of the variables used in the regressions for explaining regional employment change (table 10)

\begin{tabular}{|c|c|c|c|c|}
\hline Variable & Mean & $\begin{array}{l}\text { Standard } \\
\text { deviation }\end{array}$ & Minimum & Maximum \\
\hline & \multicolumn{4}{|c|}{ West Germany } \\
\hline $\begin{array}{l}\text { Regional employment } \\
\text { change ( } 5 \text { years) }\end{array}$ & 2.10 & 5.96 & -10.99 & 21.96 \\
\hline $\begin{array}{l}\text { Share of employees } \\
\text { with a tertiary degree }\end{array}$ & 4.94 & 2.11 & 1.55 & 14.68 \\
\hline Share of creative core & 6.11 & 1.78 & 2.49 & 13.37 \\
\hline $\begin{array}{l}\text { Share of creative } \\
\text { professionals }\end{array}$ & 23.44 & 2.29 & 17.70 & 31.15 \\
\hline $\begin{array}{l}\text { Share of creative class } \\
\text { A (without bohemians) }\end{array}$ & 29.55 & 3.83 & 20.45 & 43.24 \\
\hline $\begin{array}{l}\text { Share of employed } \\
\text { bohemians }\end{array}$ & 0.83 & 0.40 & 0.32 & 2.65 \\
\hline \multirow{2}{*}{$\begin{array}{l}\text { Share of creative class } \\
\text { B (including } \\
\text { bohemians) }\end{array}$} & 30.38 & 4.14 & 20.59 & 45.89 \\
\hline & \multicolumn{4}{|c|}{ East Germany } \\
\hline $\begin{array}{l}\text { Regional employment } \\
\text { change ( } 5 \text { years) }\end{array}$ & -12.59 & 3.33 & -18.51 & -4.00 \\
\hline $\begin{array}{l}\text { Share of employees } \\
\text { with a tertiary degree }\end{array}$ & 8.97 & 2.04 & 4.82 & 14.68 \\
\hline Share of creative core & 8.83 & 1.51 & 4.45 & 11.33 \\
\hline $\begin{array}{l}\text { Share of creative } \\
\text { professionals }\end{array}$ & 22.64 & 0.93 & 20.54 & 24.92 \\
\hline $\begin{array}{l}\text { Share of creative class } \\
\text { A (without bohemians) }\end{array}$ & 31.47 & 2.12 & 26.30 & 36.19 \\
\hline $\begin{array}{l}\text { Share of employed } \\
\text { bohemians }\end{array}$ & 0.90 & 0.25 & 0.48 & 1.67 \\
\hline $\begin{array}{l}\text { Share of creative class } \\
B \text { (including } \\
\text { bohemians) }\end{array}$ & 32.36 & 2.30 & 26.89 & 37.60 \\
\hline
\end{tabular}

Notes: Data for West Germany are for the years 1987-1999 (934 cases). Data for East Germany are for the years 1996-1999 period (84 cases). Regional employment change covers the period until 2004. 


\section{References}

Almus, Matthias, Dirk Engel and Susanne Prantl (2000): The ZEW Foundation Panels and the Mannheim Enterprise Panels of the Centre for European Economic Research (ZEW), Schmollers Jahrbuch / Journal of Applied Social Science Studies, 120, 301308.

Andersen, Kristina Vaarst and Mark Lorenzen (2005): The Geography of the Danish Creative Class: A Mapping and Analysis, Copenhagen Business School. http://www.kreativeklasse.dk/index.php?id=75.

Arora, Ashish, Richard Florida, Gary J. Gates and Mark Kamlet (2000): Human Capital, Quality of Place, and Location, Workin Paper, H.J. Heinz III School of Public Policy, Pittsburg: Carnegie Mellon University http://www.heinz.cmu.edu/ florida/.

Audretsch, David B. (1995): Innovation and Industry Evolution, Cambridge (Mas): MIT Press.

Boschma, Ron and Michael Fritsch (2007): Creative Class and Regional Growth - Empirical Evidence from eight European Countries, University of Utrecht and Friedrich-Schiller-University Jena (mimeo).

Bundesamt für Bauwesen und Raumordnung - BBR (2003): Aktuelle Daten zur Entwicklung der Städte, Kreise und Gemeinden, Band 17, Bonn.

Desrochers, Pierre (2001): Local Diversity, Human Creativity and Technological Innovation, Growth and Change, 32, 326-354.

Feldman, Maryann (2000): Location and Innovation: The New Economic Geography of Innovation, Spillovers, and Agglomeration, in: Gordon Clark, Meric Gertler and Maryann Feldman (eds.), The Oxford Handbook of Economic Geography, Oxford: Oxford University Press, 373-394.

Florida, Richard and G. Gates (2001): Technology and Tolerance: The Importance of Diversity on High Technology Growth, Washington D.C.: Brookings Institution.

Florida, Richard L. (2003): Entrepreneurship, Creativity and Regional Economic Growth, in: David M. Hart (ed.), The emergence of entrepreneurship policy: governance, start-ups, and growth in the US knowledge economy, Cambridge: Cambridge University Press.

Florida, Richard L. (2004): The Rise of the Creative Class, revised paperback edition, New York: Basic Books. 
Fritsch, Michael (2004): Entrepreneurship, Entry and Performance of New Businesses Compared in two Growth Regimes: East and West Germany, Journal of Evolutionary Economics, 14, 525-542.

Fritsch, Michael and Pamela Mueller (2004): Effects of New Business Formation on Regional Development over Time, Regional Studies, 38, 961-975.

Fritsch, Michael and Udo Brixy (2004): The Establishment File of the German Social Insurance Statistics, Schmollers Jahrbuch / Journal of Applied Social Science Studies, 124, 183-190.

Fritsch, Michael and Michael Stuetzer (2007): Die Geografie der Kreativen Klasse in Deutschland (,The Geography of the Creative Class in Germany"), Raumforschung und Raumordnung, 65 (forthcoming).

Fritsch, Michael and Viktor Slavtchev (2006): Measuring the Efficiency of Regional Innovation Systems - An Empirical Assessment, Working Paper 8/2006, Faculty of Economics and Business Administration, Technical University Bergakademie Freiberg.

Fritsch, Michael und Viktor Slavtchev (2007): What Determines the Efficiency of Regional Innovation Systems? Friedrich-SchillerUniversity Jena (mimeo).

Glaeser, Edward L. (2004): Review of Richard Florida's The Rise of the Creative Class, http://www.creativeclass.org/acrobat/GlaeserReview.pdf, (16.03.2006).

Greif, Siegfried and Dieter Schmiedl (2002): Patentatlas Deutschland Dynamik und Strukturen der Erfindungstätigkeit, Munich: Deutsches Patent- und Markenamt.

Grupp, Hariolf and Harald Legler (2000): Hochtechnologie 2000, Karlsruhe: Fraunhofer Institute for Systems and Innovation Research (ISI).

Haak, Carroll (2005): Künstler zwischen selbstständiger und abhängiger Erwerbsarbeit, Schmollers Jahrbuch - Journal of Applied Social Science Studies, 125, 4, 573-595.

Jacobs, Jane (1970): The Economy of Cities, New York: Vintage Book.

Jacobs, Jane (1985): Cities and the Wealth of Nations, New York: Vintage Book.

Klepper, Steven and Sally D. Sleeper (2005): Entry by Spinoffs, Management Science, 51, 1291-1306.

Lang, Robert and Karen Danielsen (2005): Review Roundtable: Cities and the Creative Class, Journal of the American Planning Association, 71, 203-220. 
Lee, Sam Youl, Richard Florida and G. Gates (2002): Innovation, Human Capital, and Creativity, Working Paper, Carnegie Mellon University.

Lee, Sam Youl, Richard Florida and Zoltan Acs (2004): Creativity and Entrepreneurship: A Regional Analysis of New Firm Formation, Regional Studies, 38, 879-891.

Lucas, Robert E. (1988): On the Mechanics of Economic Development, Journal of Monetary Economics, 22, 3-42.

Markusen, Ann and David King (2003): The Artistic Dividend: The Hidden Contributions of the Arts to the Regional Economy, Project on Regional and Industrial Economics, Minneapolis: University of Minnesota.

http://www.hhh.umn.edu/img/assets/6158/artistic dividend.pdf

Markusen, Ann (2006): Urban Development and the Politics of a Creative Class: Evidence from the Study of Artists, Environment and Planning A, 38, 1921-1940.

Markusen, Ann and Greg Schrock (2006): The Artistic Dividend: Urban Specialization and Economic Development Implications, Urban Studies, 43, 1661-1686.

Romer, Paul (1986): Increasing Returns and Long-Run Growth, Journal of Political Economy, 84, 5, 1002-1037.

Romer, Paul (1993): Economic Growth, in: David R. Henderson (ed.), The Fortune Encyclopedia of Economics, New York: Time Warner Books.

Wennekers, Sander and Roy Thurik (1999): Linking Entrepreneurship and Economic Growth, Small Business Economics, 13, 27-55. 